\title{
IMPLEMENTASI PP. NO. 27 TAHUN 2014 TENTANG \\ PENGELOLAAN BARANG MILIK NEGARA/DAERAH DALAM UPAYA MENINGKATKAN EFEKTIVITAS PENGELOLAAN BARANG DAN JASA
}

\author{
Noviana Hartanto ${ }^{1}$ \\ ${ }^{1}$ Program Studi Manajemen Pascasarjana Universitas Galuh Ciamis \\ email: hartantonoviana@gmail.com
}

\author{
Article History : \\ Received 8 August 2018 \\ Recieved in revished form \\ 24 September 2018 \\ Acepted 7 October 2018 \\ Available offline 29 October 2018 \\ Available online 29 October 2018
}

Language Transcript :

Indonesia (id)

Key Words :

Implementasi

Pengelolaan Barang

Efektifitas Pengelolaan

\begin{abstract}
Penelitian ini dilakukan untuk melihatimplementasi Peraturan Pemerintah Nomor 27 Tahun 2014 tentang pengelolaan barang milik negara/daerah dalam upaya meningkatkan efektivitas pengelolaan barang dan jasa. Penelitian ini menggunakan pendekatan kualitatif adapun metode yang digunakan deskriptif analisis. Teknik pengumpulan data dilakukan dengan wawancara, observasi dan dokumentasi. Dari temuan lapangan ditemukan bahwa Implementasi Peraturan Pemerintah Nomor 27 Tahun 2014 tentang Pengelolaan Barang Milik Negara di daerah dalam upaya meningkatkan efektivitas pengelolaan barang dan jasa yang meliputi perencanaan kebutuhan dan penganggaran, pengadaan, penggunaan, pemanfaatan, pengamanan dan pemeliharaan, penilaian, pemindahtanganan, pemusnahan, penghapusan, penatausahaan, dan pembinaan, pengawasan dan pengendalian secara umum telah dilaksanakan sesuai ketentuan di Kabupaten Ciamis. Namun derajat kesesuaiannya belum mencapai sebagaimana Peraturan Pemerintah Nomor 27 Tahun 2014. Kendala-kendala yang dihadapi yaitu Kualitas Sumber Daya Manusia aparatur barang masih perlu ditingkatkan, Keterbatasan sarana dan prasarana; Sistem informasi manajemen aset tetap masih perlu ditingkatkan. Upaya-upaya yang dilakukan yaitu Meningkatkan Kompetensi SDM melalui bimbingan teknis pengelolaan barang milik daerah secara konsisten dan berkesinambungan, pemenuhan sarana dan prasarana kerja bagi para pengelola barang daerah yaitu melalui pemberian komputer beserta printer bagi 7 Kelurahan dan 26 Kecamatan se-Kabupaten Ciamis. Pengembangan aplikasi sistem manajemen informasi barang daerah melalui peningkatan kapasitas sehingga mampu memenuhi data yang dibutuhkan, contohnya akumulasi penyusutan.
\end{abstract}

\section{PENDAHULUAN}

Sejak diberlakunya Undang-Undang Nomor 22 tahun 1999 yang disempurnakan dengan Undang-Undang 32 tahun 2004 Tentang Pemerintahan Daerah, Pemerintah Daerah mengalami perubahan fundamental (Syarifudin \& Herlina, 2011), dalam hubungan tata pemerintahan sekaligus membawa perubahan penting dalam pengelolaan keuangan daerah. Keberhasilan pengelolaan keuangan daerah mempunyai dampak langsung terhadap keberhasilan otonomi daerah dan sumbangan besar dalam upaya mewujudkan Good Governance. 
Sejalan dengan upaya perwujudan otonomi daerah dan Good Governance, maka harus memperhatikan akuntabilitas dalam pengelolaan keuangan daerah. Akuntabilitas merupakan bentuk pertanggungawaban pemerintah daerah yang berhasil maupun yang mengalami kegagalan dalam menjalankan tugasnya. Dalam konteks birokrasi pemerintah, akuntabilitas merupakan perwujudan kewajiban suatu instansi pemerintahan untuk mempertanggungjawabkan keberhasilan atau kegagalan pelaksanaan misi instansi bersangkutan. Manajemen suatu organisasi apapun dikatakan akuntabel apabila dalam pelaksanaan kegiatannya telah menentukan tujuan (Goal) yang tepat, mengembangkan standar yang dibutuhkan untuk mencapai tujuan, menerapkan pemakaian standar serta mengembangkan standar organisasi dan operasi searah efektif dan efisien (Darise, 2009: 19).

Manajemen pemerintahan yang efektif sangat dibutuhkan agar berbagai urusan pemerintahan dilimpahkan kewenangannya kepada daerah dan dapat terselenggara secara maksimal serta dapat dipertanggungjawabkan secara baik kepada publik.Salah satu contohnya adalah terjadinya pelimpahan kewenangan dalam hal pengelolaan aset negara (pemerintah) yang semulanya banyak ditangani oleh pemerintah pusat pada pemerintah daerah. Dengan pelimpahan kewenangan tersebut pemerintah daerah memiliki kewenangan yang lebih besar dalam pengelolaan aset Negara.

Aset tetap atau barang milik daerah merupakan salah satu faktor yang paling strategis dalam pengelolaan keuangan daerah. Pada umumnya, nilai aset tetap daerah merupakan nilai yang paling besar dibandingkan dengan akun lain pada laporan keuangan. Keberadaan aset tetap sangat mempengaruhi kelancaran roda pemerintahan dan pembangunan. Oleh karena itu, sistem pengendalian intern atas manajemen/pengelolaan aset tetap daerah harus handal untuk mencegah penyimpangan yang dapat merugikan keuangan daerah

Aset tetap/barang milik daerah memiliki fungsi yang sangat penting dalam penyelenggaraan pemerintahan, tetapi dalam pelaksanaan pengelolaan barang milik daerah bukan hal yang mudah sering kali terdapat berbagai persoalan aset daerah. Hal ini terbukti dari masih banyaknya pengecualian kewajaran atas nilai aset pemerintah daerah dalam opini BPK-RI atas laporan keuangan pemerintah daerah. Kondisi tersebut mengindikasikan bahwa pemerintah daerah mengalami kesulitan dalam pengelolaan aset sehingga laporan hasil pemeriksaan (LHP) dari BPK menemukan adanya kelemahan dalam pengelolaan aset.

Pengelolaan barang milik daerah dilaksanakan berdasarkan asas fungsional, kepastian hukum, transparansi dan keterbukaan, efisiensi, akuntabilitas, dan kepastian nilai. Usaha mengelola barang milik daerah secara akurat dan akuntabel memerlukan komitmen yang tinggi dari seluruh jajaran, mulai dari tingkat SKPD sampai dengan tingkat kepala daerah agar seluruh barang milik daerah dapat dipertanggungjawabkan, baik secara fisik maupun administrasi pelaporannya.

Persoalan-persoalan dalam pengelolaan barang milik daerah seringkali muncul karena pengguna barang milik daerah tidak memahami tugas dan kewajibannya sebagai pengguna barang milik daerah sesuai dengan yang tercantum dalam Peraturan Pemerintah Nomor 27 Tahun 2014 tentang Pengelolaan Barang Milik Negara/Daerah. Pengguna barang tidak memahami pentingnya kedudukan barang milik daerah sebagai satu kesatuan tak terpisahkan dari keuangan daerah. Penggunaan adalah kegiatan yang dilakukan oleh pengguna/kuasa pengguna dalam mengelola 
dan menata usahakan barang milikdaerah sesuai dengan tugas pokok dan fungsi Satuan Kerja Perangkat Daerah (SKPD) yang bersangkutan. Seringkali terjadi kesalahan dan kelalaian dalam pengelolaan barang milik daerah karena penggunaan barang milik daerah tidak sesuai dengan aturan yang berlaku.

Selain pengguna barang, kemampuan pengurus barang dalam mengelola barang milik daerah sesuai dengan aturan yang berlaku juga sangat menentukan keberhasilan pengelolaan barang milik daerah. Menurut Peraturan Pemerintah Nomor 27 Tahun 2014 tentang Pengelolaan Barang Milik Negara/Daerah bahwa pengurus barang milik daerah adalah pegawai yang diserahi tugas untuk mengurus barang daerah dalam proses pemakaian yang ada di setiap satuan kerja perangkat daerah/unit kerja. Pemahaman aparatur pengurus barang tentang tugas dan kewajibannya dalam mengelola barang milik daerah sangat menentukan ketertiban penatausahaan barang milik daerah.

Berdasarkan data yang diperoleh dari BPKD sebagai pembantu pengelola Barang Milik Daerah diperoleh Neraca aset 2015 dan 2016 sebagai berikut:

Tabel1. Neraca Aset Tahun 2015-2016

\begin{tabular}{|c|c|c|}
\hline Uraian & 2015 & 2016 \\
\hline Tanah & $251.954 .194 .973,00$ & $267.410 .467 .155,96$ \\
\hline $\begin{array}{l}\text { Peralatan dan } \\
\text { Mesin }\end{array}$ & $427.036 .473 .106,28$ & $552.215 .929 .639,14$ \\
\hline $\begin{array}{l}\text { Gedung dan } \\
\text { Bangunan }\end{array}$ & $\begin{array}{c}1.026 .298 .258 .542,4 \\
6\end{array}$ & $\begin{array}{c}1.355 .010 .087 .198,8 \\
8\end{array}$ \\
\hline $\begin{array}{l}\text { Jalan, Jaringan } \\
\text { dan Jembatan }\end{array}$ & $\begin{array}{c}1.424 .274 .163 .544,0 \\
0\end{array}$ & $\begin{array}{c}1.993 .788 .527 .620,0 \\
1\end{array}$ \\
\hline $\begin{array}{l}\text { Aset Tetap } \\
\text { Lainnya }\end{array}$ & $89.128 .330 .642,88$ & $7.020 .158 .822,00$ \\
\hline $\begin{array}{l}\text { Konstruksi } \\
\text { Dalam } \\
\text { Penyelesaian }\end{array}$ & $22.360 .357 .325,00$ & $45.178 .753 .100,00$ \\
\hline Total & $\begin{array}{c}3.241 .051 .778 .133,6 \\
2\end{array}$ & $\begin{array}{c}4.220 .623 .923 .535,9 \\
9\end{array}$ \\
\hline
\end{tabular}

Berdasarkan data diatas bahwa total aset Kabupaten Ciamis terdapat peningkatan, akan tetapi hasil observasi pada Pemerintah Kabupaten Ciamis bahwa pengelolaan barang milik daerah belum optimal hal ini disebabkan beberapa hal yaitu penilaian aset belum memadai, tingkat sumber daya manusia masih kurang, penguasaan terhadap sistem aplikasi BMD masih kurang, perhatian pimpinan SKPD terhadap BMD masih kurang, penatausahaan BMD belum dilakukan secara efisien, laporan BMD belum akurat dan keberadaan/eksistensi aset masih lemah (berkaitan dengan kepemilikan aset berupa tanah).

Penelitian ini ditujukan untuk mempelajari, mengetahui, dan menganalisis Implementasi Peraturan Pemerintah Nomor 27 Tahun 2014 tentang Pengelolaan Barang Milik Negara/Daerah Dalam Upaya Meningkatkan efektivitas pengelolaan Barang dan Jasa (Studi pada Badan Pengelolaan Keuangan Daerah Kabupaten Ciamis).

\section{METOOLOGI}

Pendekatan penelitian yang digunakan adalah pendekatan kualitatif. Menurut Sugiyono (2010:9) metode kualitatif yaitu metode penelitian yang berlandaskan pada filsafat positivisme, digunakan untuk meneliti pada kondisi objek yang alamiah (sebagai lawannya eksperimen) dimana peneliti dalah sebagai instrumen kunci, teknik pengumpulan data yang dilakukan secara triangulasi (gabungan), analisis data bersifat kualitatif dan hasil penelitian lebih menekankan makna generalisasi.

Penelitian ini dilaksanakan dari bulan Oktober 2016-April 2017 di Badan Pengelolaan Keuangan Daerah Kabupaten Ciamis yang beralamat di Jalan Drs. H. Soejoed No. 5A Kertasari Kecamatan Ciamis Kabupaten Ciamis telepon (0265) 771032 .

Keabsahan dan keajekan penelitian ini diuji dengn cara melakukan proses triangulasi 
secara terus menerus sejak data dideskripsikan, dianalisis, ditafsirkan hingga data tersebut disimpulkan sebagai upaya menjawab masalah penelitian.

Teknik analisis data menggunakan teknik kualitatif yaitu upaya yang dilakukan dengan jalan bekerja dengan data, mengorganisasikan data, memilah-milahnya menjadi santun yang dapat dikelola, mensintesiskannya mencari dan menemukan pola, menemukan apa yang penting dan apa yang dipelajari dan memutus apa yang dapat diceritakan kepada orang lain (Meleong, 2009: 248).

Analisis data kualitatif yaitu dilakukan secara berangsur sampai selesai mendapatkan sekumpulan data dari wawancara, observasi atau dokumen dengan menguraikan data-data yang diperoleh kemudian diambil kesimpulan.Penerapan teknik dalam analisis data adalah Reduksi data, Display data, Triangulasidata dan Pengambilan kesimpulan dan verifikasi.

\section{HASIL DAN PEMBAHASAN}

\subsection{Implementasi Peraturan Pemerintah} Nomor 27 Tahun 2014 tentang Pengelolaan Barang Milik Negara/Daerah dalam Upaya Meningkatkan Efektivitas Pengelolaan Barang dan Jasa.

Berdasarkan hasil wawancara dengan Kepala Sub Bidang Perencanaan, Pengadaan dan Penghapusan Barang Milik Daerah (HS), Kepala Sub Bidang penatausahaan dan pelaporan Barang Milik Daerah (DS), Kepala Sub Bidang pemanfaatan dan pengamanan Barang Milik Daerah (WS), Kepala Sub Bidang Umum dan Kepegawaian (DR) dan Pengurus barang Badan Pengelolaan Keuangan Daerah Kabupaten Ciamis (MN), observasi dan dokumentasi dapat disimpulkan bahwa Implementasi Peraturan Pemerintah Nomor 27 Tahun 2014 tentang
Pengelolaan Barang Milik Negara/Daerah dalam upaya meningkatkan efektivitas pengelolaan barang dan jasa terdapat 11 siklus pengelolaan BMD telah dilaksanakan sesuai dengan ketentuan akan tetapi terdapat beberapa hal yang harus dioptimlkan untuk lebih jelas berikut ini dijelasakan secara rinci 11 siklus pengelolaan BMD yang dilakukan yaitu sebagai berikut:

\section{1) Perencanaan Kebutuhan Dan Penganggaran}

Perencanaan Kebutuhan adalah kegiatan merumuskan rincian kebutuhan barang milik daerah untuk menghubungkan pengadaan barang yang telah lalu dengan keadaan yang sedang berjalan sebagai dasar dalam melakukan tindakan yang akan datang.

Berdasarkan hasil wawancara, observasi dam dokumentasi, Badan Pengelola Keuangan Daerah Ciamis selaku SKPD telah menyusun perencanaan kebutuhan dan pemeliharaan barang milik daerah dengan berpedoman pada standarisasi sarana dan prasarana kerja pemerintahan daerah yang ditetapkan dengan Peraturan Kepala Daerah dan standar harga yang ditetapkan dengan Keputusan Kepala Daerah.

Berdasarkan standar harga yang telah ditetapkan, dijadikan dasar menyusun rencana kebutuhan barang milik daerah dan rencana kebutuan pemeliharaan barang milik daerah. Daftar rincian kebutuhan telah dijadikan sebagai dasar penyusunan Rencana Kerja dan Anggaran (RKA) dan bahan penyusunan rencana APBD. Selanjutnya dengan memperhatikan data barang pada pengguna (BPKD), maka diusun rencana kebutuhan pemeliharaan barang unit (RKPBU) untuk dijadikan sebagai dasar penysunan RKA SKPD.

Berdasarkan Peraturan Pemerintah Nomor 24 Tahun 2014 pengelola bersama pengguna membahas usul rencana kebutuhan barang milik daerah dan rencana 
kebutuhan pemeliharaan barang milik daerah masing-masing SKPD dengan memperhatikan data barang pada pengguna dan/atau pengelola untuk ditetapkan sebagai RKBMD dan RKPBMD.

Selaku pembantu pengelola barang (BPKD) semua RKBU dan RKPBU dari semua SKPD di susun untuk dijadikan bahan dalam penyusunan DKBMD dan DKPBMD. Setelah APBD ditetapkan, pembantu pengelola barang menyusun DKBMD dan DKPBMD, sebagai dasar pelaksanaan pengadaan dan pemeliharaan barang milik daerah.

Berdasarkan hasil dokumentasi DKBMD dan DKPBMD telah dibuat sesuai dengan Peraturan Pemerintah Nomor 27 Tahun 2014 dan Permendagri Nomor 19 Tahun 2016 tentang pedoman Pengelolaan Barang Milik Daerah.

\section{2) Pengadaan}

Berdasarkan hasil wawancara, observasi dan dokumentasi proses pengadaan barang/jasa pemerintah telah dilaksanakan sesuai ketentuan yang mana tata caranya mengacu kepada Penpres Nomor 70 Tahun 2012, Bupati Ciamis selaku Kepala Daerah telah melimpahkan kewenangan kepada SKPD untuk membentuk Panitia Pengadaan Barang/jasa serta panitia pemeriksa barang/jasa. Pada BPKD Kabupaten Ciamis, baik untuk pejabat pengadaan maupun panitia pemeriksa barang telah dibuat yang ditetapkan oleh Kepala Badan.

Pejabat pengadaan ini tidak saja melakukan proses pengadaan barang/jasa pada SKPD bersangkutan akan tetapi juga melakukan proses pengadaan barang/jasa bagi SKPD lain, dikarenakan masih terbatasnya tenaga ahli pengadaan barang/jasa yang memiliki kualifikasi pengadaan barang/jasa pemerintah.

BPKD berdasarkan Dokumen Pelaksanaan Anggaran (DPA) yang ada telah melaksanakan proses pengadaan barang/jasa sesuai ketentuan diatas. Kepala bidang selaku Kuasa Pengguna Anggaran (KPA) berdasarkan DPA yang ada menyusun Kerangka Acuan Kerja (KAK) sesuai program kegiatan untuk jenis barang yang akan dibeli. Selanjutnya menyusun harga perkiraan sendiri (HPS). KAK beserta HPS selanjutnya diserahkan kepada pejabat pengadaan yang akan dijadikan dasar untuk pelaksanaan pengadaan barang/jasa.

Menurut Peraturan Pemerintah Nomor 27 Tahun 2014, Kepala SKPD menyusun dan menyampaikan laporan barang pengguna semesteran dan laporan barang pengguna tahunan yang berada dalam penguasaannya kepada Pengelola Barang (Sekda). Hal ini telah dilaksanakan sesuai dengan ketentuan yang berlaku.

\section{3) Penggunaan}

Berdasarkan Pasal 18 Peraturan Pemerintah Nomor 27 Tahun 2014 bahwa Barang Milik Negara/Daerah dapat ditetapkan status penggunaannya untuk penyelenggaraan tugas dan fungsi Kementerian/Lembaga/satuan kerja perangkat daerah, guna dioperasikan oleh Pihak Lain dalam rangka menjalankan pelayanan umum sesuai tugas dan fungsi Kementerian/ Lembaga/satuan kerja perangkat daerah yang bersangkutan.

Berdasarkan hasil wawancara, observasi dan wawancara penetapan penggunaan barang milik daerah untuk penyelenggaraan tugas pokok dan fungsi SKPD pada BPKD Kabupaten Ciamis telah dilaksanakan tetapi hal ini baru terbatas pada barang seperti tanah dan bangunan. Begitu juga selaku pembantu pengelola, penetapan barang milik daerah yang dibeli oleh masingmasing SKPD telah dilaksanakan sesuai ketentuan.

Akan tetapi untuk barang diluar tanah dan bangunan belum dilaksanakan. Artinya untuk barang-barang seperti kendaraan roda dua, roda empat dan barang milik daerah lainnya belum ditetapkan status penggunaannya, hal ini disebabkan adanya pemahaman barang tersebut telah mengikat status penggunaannya karena dari proses 
pengganggaran sampai pengadaannya menjadi tanggung jawab SKPD masingmasing.

Penetapan status penggunaan barang milik daerah telah dilaksanakan sesuai ketentuan. pengguna atas dasar permohonan dari pihak ketiga menyampaikan permohonan dari pihak ketiga menyampaikan permohonan penggunaan tanah milik Pemda kepada Kepala Daerah, setelah itu tim pengkaji memproses usulan tersbut dan hasilnya disampaikan kembali kepada Kepala Daerah, apabila disetujui maka oleh tim pengkaji surat tadi diteruskan ke BPKD untuk dibuatkan Surat Keputusan Bupatinya. Selanjutnya atas dasar keputusan tadi dilanjutkan dengan pembuatan Surat Kesepakatan (MOU) tentang penggunaan tanah milik Pemda antara pihak Pemda dengan pihak ketiga. Atas dasar surat kesepakatan tersebut selanjutnya diterbitkan Surat Ketetapan Retribusi Daerah (SKRD) yang hasilnya disetorkan ke Kas Umum Daerah sebagai pendapatan asli daerah. Penyetoran ke kas daerah dilakukan oleh pihak (petugas) dari UPTD BPKD sesuai wilayah kerjanya.

\section{4) Pemanfaatan}

Di Kabupaten Ciamis, bentuk pemanfaatan barang milik daerah yang telah dilaksanakan adalah sewa dan pinjam pakai. Berdasarkan hasil wawancara, observasi dan dokumentasi Untuk barangbarang yang penguasaannya berada pada pengguna barang (SKPD), maka proses penatausahaan dilaksanakan oleh SKPD yang bersangkutan setelah mendapat persetujuan Kepala Daerah. Sedangkan untuk barang-barang yang penguasaannya berada pada pengelola barang, maka penatausahaan peanfaatan sewa barang milik daerah dilaksanakan oleh pembantu pengelola melalui bidang pengelolaan barang milik daerah pada BPKD yang meliputi sewa tanah dan bangunan.

Untuk pemanfaatan melalui pinjam pakai semua dilaksanakan oleh pembantu pengelola setelah memperoleh izin dari kepala daerah meliputi barang milik daerah yang dimanfaatkan oleh instansi vertikal baik tanah, bangunan maupun kendaraan roda dua dan roda empat.
Pemanfaatan barang milik daerah melalui sewa maupun pinjam pakai telah dilaksanakan sesuai ketentuan. Izin pemanfaatan barang milik daerah apabila telah disetujui oleh Kepala Daerah maka diterbitkan SK Bupati tentang izin pemanfaatan tanah tersebut. Selanjutnya berdasarkan surat keputusan izin penggunaan tersebut ditindaklanjuti dengan pembuatan surat perjanjian (MOU) sewa menyewa antara pihak penyewa dengan pihak pemerintah daerah yang dalam hal ini oleh pengelola (sekretaris daerah). Berdasarkan Peraturan Pemerintah Nomor 27 Tahun 2014 Bahwa Pendapatan daerah dari pemanfaatan barang milik daerah merupakan penerimaan daerah yang wajib disetorkan seluruhnya ke rekening Kas Umum Daerah.

Pemanfaatan barang daerah melalui pinjam pakai dilaksanakan antara pemerintah daerah denga inisiasi vertikal yang berada di Kabupaten Ciamis. Jenis barang yang dimanfaatkan untuk dipinjamkan meliputi tanah, bangunan, kendaraan roda dua dan roda empat. Pinjam pakai barang milik daerah dilaksanakan oleh pengelola (Sekda) setelah mendapat persetujuan dari Kepala Daerah. Surat Keputusan Bupati tentang pinjam pakai BMD dan ditindaklanjuti dengan penandatanganan surat perjanjian (MOU) pinjam pakai barang dimaksud, yang isinya memuat: pihak-pihak yang terikat dalam perjanjian, jenis, luas atau jumlah barang, jangka waktu peminjaman, tanggungjawab peminjam atas biaya operasional dan pemeliharaan waktu peminjaman dan persyaratan lain yang dianggap perlu. Berdasarkan Peraturan Pemerintah Nomor 27 tahun 2014, jangka waktu perpanjangan waktu pinjaman adalah 5 (lima) tahun dan dapat diperpanjang satu kali.

\section{5) Pengamanan Dan Pemeliharaan}

Berdasarkan hasil wawancara, observasi dan dokumentasi, Pengelola Barang, Pengguna Barang dan/atau Kuasa Pengguna Barang telah melakukan pengamanan Barang Milik Daerah yang berada dalam penguasaannya. Pengamanan barang milik daerah meliputi: 
- Pengamanan administrasi meliputi kegiatan pembukuan, inventarisasi, pelaporan dan penyimpanan dokumen kepemilikan.

- Pengamanan fisik untuk mencegah terjadinya penurunan fungsi barang, penurunan julah barang dan hilangnya barang.

- Pegamanan fisik untuk tanah dan bagunan dilakukan dengan cara pemagaran dan pemasangan tanda batas (patok), selain tanah dan bangunan dilakukan dengan cara penyimpanan dokumen (BPKB, Sertifikat tanah) dalam brankas tahan api dan pemeliharaan yang dituangkan dalam Dokumen Pelaksanaan Anggaran.

- Pengamanan hukum antara lain meliputi kegiatan melengkapi bukti status kepemilikan (BPKB dan Sertifikat).

\section{6) Penilaian}

Berdasarkan hasil wawancara, observasi dan dokumentasi BPKD telah melaksanakan penilaian barang milik daerah sesuai ketentuan baik untuk penyusunan neraca pemerintah daerah, pemanfaatan dan pemindahtanganan barang milik daerah.

Penilaian barang milik daerah yang dilaksanakan pada BPKD selaku pengguna barang untuk keperluan dalam rangka pengadaaan tanah pemda. Sedangkan selaku pembantu pengelola barang milik daerah, penilaian barang milik daerah dilaksanakan untuk keperluan pemindahtangan barang milik daerah berupa hibah, baik hibah dari Pemda kepada pihak ketiga maupun sebaliknya.

Untuk penyusunan neraca pemerintah daerah, tidak dilakukan lagi penilaian barang milik daerah, artinya nilai yang digunakan dalam neraca adalah nilai barang hasil perolehan. Sedangkan penilaian barang milik daerah yang dilakukan adalah dalam proses penghapusan barang, penilaian barnag milik daerh ini dilakukan terhadap bangunan yang masih memiliki nilai ekonomisnya.
Proses penilaian barang milik daerah, baik untuk kepentingan pemidahtanganan maupun penghapusan telah dilaksanakan sesuai prosedur yang berlaku. Barang yang akan dihapuskan, setelah disetujui oleh Kepala Daerah, selanjutnya dimohonkan kepada pihak Kantor Pelayanan Kekayaan Negara dan Lelang (KPKNL) untuk dilakukan penilaian dan penaksiran sehingga diketahui barang yang masih memiliki nilai ekonomisnya. Hasil penilaian ini dijadikan dasar untuk proses penghapusan yang ditindaklanjuti dengan pelelangan. Dokumen dari mulai permohonan penghapusan barang dari SKPD sampai dengan bukti penyetoran hasil pelelangan ke kas daerah telah dilakukan dan menjadi bukti pertanggungjawaban pelaksanaan penghapusan barang milik daerah.

\section{7) Pemindahtanganan}

Pemindahtangan barang milik daerah adalah pengalihan kepemilikan sebagai tindak lanjut dari penghapusan. Bentukbentuk pemindahtangan meliputi: penjualan dan tukar-menukar, hibah serta penyertaan modal.

Berdasarkan hasil wawancara, observasi dan dokumentasi proses pemindahtangan barang milik daerah telah dilaksanakan sesuai ketentuan, dalam hal ini selaku pengguna barang BPKD terbatas hanya sampai pada proses mengajukan permohonan pemindahtangan, selanjutnya sebagai tindak lanjut dari pemindahtangan tersebut yang meliputi: penjualan dan tukar menukar, hibah serta penyertaan modal dilaksanakan oleh Kepala BPKD selaku pembantu pengelola barang.

Penjualan barang milik daerah prosesnya dilakukan bekerjasama dengan Kantor Pelayanan Kekayaan Negara dan Lelang (KPKNL) dan hasil penjualan/pelelangan tersebut sepenuhnya telah disetorkan ke kas daerah. Untuk proses tukar menukar, baik tanah maupun bangunan berdasarkan data yang ada belum dilakukan. Sedangkan untuk proses hibah barang milik daerah telah dilaksanakan sesuai ketentuan, baik hibah dari pemerintah daerah kepada pihak ketiga maupun sebaliknya dari pihak ketiga pemerintah daerah. Hibah dari pihak ketiga kepada pemerintah daerah berupa tanah dan 
bangunan, sedangkan hibah dari pihak pemerintah daerah kepada pihak ketiga berupa kendaraan roda dua, roda empat serta sisa hasil bongkaran barang yang akan dihapuskan.

Berdasarkan Peraturan pemerintah Nomor 27 tahun 2014 bahwa Pemindahtanganan Barang Milik Negara/Daerah dilakukan dengan cara: Penjualan, Tukar Menukar, Hibah atau Penyertaan Modal Pemerintah Pusat/Daerah. Kepala daerah melaporkan kepada Menteri Dalam Negeri selambatlambatnya 15 (lima belas) hari setelah ditetapkan Keputusan penghapusan belum sesuai ketentuan, disebabkan kurangnya pemahaman atas peraturan yang ada.

\section{8) Pemusnahan}

Pemusnahan Barang Milik Daerah dilakukan dalam hal Barang Milik Daerah tidak dapat digunakan, tidak dapat dimanfaatkan, dan/atau tidak dapat dipindahtangankan; atau terdapat alasan lain sesuai dengan ketentuan peraturan perundang-undangan.

Berdasarkan hasil wawancara, observasi dan dokumentasi dalam pemusnahan barang milik daerah telah dilaksanakan sesuai dengan Peraturan Pemerintah Nomor 27 Tahun 2014 dimana Pemusnahan dilaksanakan oleh Pengguna Barang setelah mendapat persetujuan Bupati, untuk barang milik daerah pada Pengguna Barang. Dan pemusnahan dilaksanakan oleh Pengelola Barang setelah mendapat persetujuan Bupati, untuk barang milik daerah pada Pengelola Barang.

Dalam proses pemusnahan barang milik daerah, pengelola Barang (Sekda) melakukan penelitian terhadap permohonan usulan Pemusnahan, Penelitian tersebut meliputi: penelitian kelayakan pertimbangandan alasan permohonan pemusnahan barang milik daerah, penelitian data administratif dan penelitian fisik. Penelitian data administratif dilakukan untuk meneliti antara lain: kode barang, kode register, nama barang, tahun perolehan, spesifikasi barang, kondisi barang, jumlah barang, bukti kepemilikan untuk barang milik daerah yang harus dilengkapi dengan bukti kepemilikan, nilai perolehan, dan/atau nilai buku, untuk barang milik daerahyang dapat dilakukan penyusutan.

Penelitian fisik dilakukan dengan cara mencocokkan fisik barang milik daerah yang akan dimusnahkan dengan data administratif. Pengelola Barang menyampaikan hasil penelitian kepada Kepala Daerah sebagai bahan pertimbanganpersetujuan pemusnahan barang milik daerah.Pengelola Barang (Sekda) menyampaikan hasil penelitian kepada Bupati sebagai bahan pertimbangan persetujuan pemusnahan barang milik daerah.

Apabila permohonan pemusnahan barang milik daerah tidak disetujui, Bupati memberitahukan kepada Pengelola Barang disertai dengan alasan. Apabila permohonan pemusnahan barang milik daerah disetujui Bupati menerbitkan surat persetujuan pemusnahan barang milik daerah. Surat persetujuan pemusnahan barang milik daerah memuat: data barang milik daerah yang disetujui untuk dimusnahkan, yang sekurang-kurangnya meliputi kode barang, kode register, nama barang, tahun perolehan, spesifikasi barang, kondisi barang, jumlah barang, nilai perolehan,dan nilai bukuuntuk barang milik daerah yang dapat dilakukan penyusutan dan kewajiban Pengelola Barang untuk melaporkan pelaksanaan pemusnahan kepada Bupati.

Berdasarkan persetujuan pemusnahan barang milik daerah, Pengelola Barang melakukan pemusnahan barang milik daerah. Pelaksanaan pemusnahan dituangkan dalam berita acara pemusnahan dan dilaksanakan paling lama 1 (satu) bulan sejak tanggal persetujuan pemusnahan barang milik daerah dari Bupati. Berdasarkan berita acara pemusnahan 
Pengelola Barang mengajukan usulan penghapusan barang milik daerah.

\section{9) Penghapusan}

Penghapusan barang milik daerah meliputi penghapusan dari daftar pengguna dan/atau kuasa pengguna dan penghapusan dari daftar barang milik daerah.

Berdasarkan hasil wawancara, observasi dan dokumentasi BPKD telah melakukan proses penghapusan barang milik daerah dari daftar penguna mauun dari daftar milik daerah telah dilaksanakan sesuai ketentuan.

Selaku pembantu pengelola dalam melaksanakan proses penghapusan BMD didasarkan pada pertimbangan antara lain : pertimbangan teknis karena secara fisik barang tidak dapat digunakan karena rusak dan tidak ekonomis bila diperbaiki, laju pertimbangan ekonomis karena lebih menguntungkan bagi daerah apabila dihapus, karena biaya operasional dan pemeliharaannya lebih besar dari manfaat yang diperoleh.

Berkas dokumen dari mulai usulan permohonan penghapusan, berkas hasl penilaian barang daerah dan Surat Keputusan Bupati tetang persetujuan penghapusan barang milik daerah telah dibuat dan disusun sebagai bukti pertanggungjawaban pelaksanaan penghapusan barang milik daerah.

\section{0) Penatausahaan}

Penatausahaan barang milik daerah meliputi pembukuan, inventarisasi dan pelaporan. Berdasarkan hasil wawancara, observasi dan dokumentasi penatausahaan barang milik daerah meliputi kegiatan pembukuan, inventarisasi dan pelaporan telah dilaksanakan sesuai ketentuan.

Kepala BPKD selaku pengguna barang telah melakukan kegiatan pembukuan barang daerah melalui pendaftaran dan pencatatan barang milik daeah ke dalam daftara barang pengguna dan telah dilakukan kodefikasi dan labelisasi barang. Pendaftaran dan pencatatan barang tersebut, baik barang yang berasal dari pengadaan maupun dari mutasi antar SKPD. Selanjutnya pencatatan barang telah dimuat dalam Kartu Inventarisasi Barang (KIB) dan Kartu Inventaris Ruangan (KIR).
Sedangkan selaku pembantu pengelola, BPKD melalui Bidang Pengelolaan Barang Milik Daerah telah melakukan rekapitulasi atas pencatatan dan pendaftaran barang milik daerah dari seluruh SKPD. Pencatatan pada Kartu Inventaris Barang (KIB) telah disesuaikan dengna kebijakan akuntansi terutama kapitalisasi aset tetap.

Pemerintah daerah Kabupaten Ciamis telah melaksanakan sensus barang tahun 2013 yang dilaksanakan secara populasi tidak menggunakan sampel, artinya sensus barang dilakukan kepada seluruh SKPD sampai unit pengguna yaitu Puskesmas, UPTD, Sekolah Dasar, SLPN dan SMAN/SMKN.

Pelaporan barang milik daerah, baik secara berjenjang maupun periodik dilaksanakan sesuai ketentuan. Selaku pengguna barang BPKD telah menyusun laporan barang milik daerah, baik sementara maupun tahun kepada pengelola barang (Sekda) melalui Pembantu Pengelola Barang (BPKD) yang akan dihimpun menjadi Laporan Barang Milik Daerah (LBMD) untuk disampaikan kepada Kepala Daerah melalui Pengelola. Isi laporan sebagaimana dimaksud telah memuat mengenai rincian aset tetap yang terdiri : tanah (KIB A), Peralatan dan Mesin (KIB B), Gedung dan Bangunan (KIB C), Jalan, Irigasi, dan Jaringan (KIB D), Aset Tetap lainnya (KIB E), Konstruksi dalam Pengerjaan (KIB F) serta Akumulasi Penyusutan. Laporan Sebagaimana dimaksud selanjutnya digunakan sebagai bahan untuk menyusun Neraca Pemerintah Daerah.

\section{1) Pembinaan, Pengawasan Dan Pengendalian}

Berdasarkan hasil wawancara, observasi dan dokumentasi BPKD dalam rangka tertib administrasi pengelolaan barang milik daerah telah melaksanakan pembinaan, pengawasan dan pengendalian barang milik daerah. Kegiatan dilakukan antara lain:

- Memberikan bimbingan teknis dalam hal penatausahaan dan pengelolaan barang milik daerah;

- Menempatkan personil sebagai pengurus barang yang masih muda dan memiliki 
wawasan dalam hal pengelolaan dan penatausahaan barang milik daerah; dan

- Bimbingan Teknis pengelolaan barang milik daerah bekerja sama dengan Bagian Pendidikan dan Latihan (Diklat) Kemendagri Perwakilan Jawa barat dan Lembaga Administrasi Negara (LAN)

Bentuk pengendalian dalam rangka pengelolaan barang milik daerah dilaksanakan dengan cara melalui kegiatan rekonsiliasi dan aset daerah secara berkala setiap awal bulan. Seluruh SKPD melalui pengeurus barang atau operator SIMDABMD melakukan rekonsiliasi data aset saerah untuk periode bulan sebelumnya yang hasilnya dituangkan dalam berita acara rekonsiliasi aset daerah yang memuat tentang realisasi belanja modal, mutasi aset, baik bertambah maupun berkurang serta perpindahan atau reklas antar KIB. Hasil rekonsiliasi ini kemudian di konsilidasi oleh pembantu pengelolaan menjadi bahan laporan BMD Kabupaten.

Dalam hal pengawasan dan pengendalian, dilaksanakannya kegiatan Rapat koordinasi bagi para Kasubag umum dan pengurus barang seluruh SKPD secara berkala setiap tiga bulan sekali. Disamping itu juga dilaksanakan kegiatan rekonsiliasi data aset tetap antara seluruh SKPD dengan Bidang Pengelolaan Barang Milik Daerah selaku pembantu pengelola barang daerah yang dilaksanakan setiap awal bulan.

Berdasarkan hasil penelitian dilapangan mulai dari wawancara, observasi dan dokumentasi, dapat disimpulkan bahwa implementasi Peraturan Pemerintah Nomor 27 Tahun 2014 tentang Pengelolaan Barang Milik Negara/Daerah yang meliputi perencanaan kebutuhan dan penganggaran, pengadaan, penggunaan, pemanfaatan, pengamanan dan pemeliharaan, penilaian, pemindahtanganan, pemusnahan, penghapusan, penatausahaan, dan pembinaan, pengawasan dan pengendalian secara umum telah dilaksanakan sesuai ketentuan di Kabupaten Ciamis.
Pengelolaan Pengelolaan barang milik negara/daerah dapat dijelasakan sebagai berikut:

a) Perencanaan kebutuhan adalah kegiatan merumuskan rincian kebutuhan barang milik negara/daerah untuk menghubungkan pengadaan barang yang telah lalu dengan keadaan yang sedang berjalan sebagai dasar dalam melakukan tindakan yang akan datang.

b) Pengadaan merupakan rangkaian kegiatan yang dilakukan untuk memiliki barang milik negara/daerah melalui suatu rangkaian proses baik melalui jual beli, maupun lelang.

c) Penggunaan adalah kegiatan yang dilakukan oleh pengguna barang dalam mengelola dan menatausahakan barang milik negara/daerah yang sesuai dengan tugas dan fungsi instansi yang bersangkutan.

d) Pemanfaatan adalah pendayagunaan barang milik negara/daerah yang tidak digunakan untuk penyelenggaraan tugas dan fungsi kementerian/ lembaga/satuan kerja perangkat daerah dan/atau optimalisasi barang milik negara/daerah dengan tidak mengubah status kepemilikan.

e) Pengamanan dan pemeliharaan merupakan rangkaian kegiatan yang dilakukan pengelola barang, pengguna barang dan kuasa pengguna barang untuk mengamankan dan memelihara barang milik negara/daerah.

f) Penilaian adalah proses kegiatan untuk memberikan suatu opini nilai atas suatu objek penilaian berupa barang milik negara/daerah pada saat tertentu.

g) Pemindahtanganan adalah pengalihan kepemilikan barang milik negara/daerah.

h) Pemusnahan adalah tindakan memusnahkan fisik dan/atau kegunaan barang milik negara/daerah. 
i) Penghapusan adalah tindakan menghapus barang milik negara/daerah dari daftar barang dengan menerbitkan keputusan dari pejabat yang berwenang untuk membebaskan pengelola barang, pengguna barang, dan/atau kuasa pengguna barang dari tanggung jawab administrasi dan fisik atas barang yang berada dalam penguasaannya.

j) Penatausahaan adalah rangkaian kegiatan yang meliputi pembukuan, inventarisasi, dan pelaporan barang milik negara/daerah sesuai dengan ketentuan peraturan perundangundangan.

k) Pembinaan, pengawasan dan pengendalian merupakan rangkaian kegiatan yang dilakukan pengelola barang untuk melakukan pengendalian serta pengawasan atas barang milik negara yang berada pada pengguna barang dan kuasa pengguna barang.

Berdasarkan wawancara dengan Sekretaris BPKD Kabupaten Ciamis (H. Kurniawan, S.E., Ak. M.Si. CA) bahwa "derajat kesesuaian dalam pengelolaan Barang Milik Daerah. belum mencapai sebagaimana Peraturan Pemerintah Nomor 27 Tahun 2014", hal ini disebabkan terdapat beberapa tahapan yang belum dilaksanakan sesuai ketentuan, diantaranya:

a) Dalam hal pelaporan hasil pemeliharaan barang belum dilaksanakan sesuai ketentuan, artinya selaku pengguna barang (SKPD) belum membuat daftar hasil pemeliharaan barang yang harus dilaporkan kepada pengelola secara berkala kepada pengelola (Sekretaris Daerah), sehingga selaku pembantu pengelola barang daerah (BPKD) tidak dapat meneliti dan menyusun daftar hasil pemeliharaan barang dalam satu tahun anggaran untuk dijadikan bahan evaluasi.

b) Pengamanan barang milik daerah khususnya pengamanan yang bersifat fisik seperti pemagaran seluruh tanah milik pemerintah daerah belum dilaksanakan sesuai ketentuan. Hal ini terjadi disebabkan banyaknya serta luasnya bidang tanah yang harus dipagar. Meskipun bila hal ini dilakukan akan berpengaruh terhadap anggaran yang harus disediakan pihak pemerintah daerah. Namun kedepannya secara bertahap pengamanan melalui pemagaran tanah milik pemerintah daerah akan dilaksanakan sesuai kemampuan keuangan daerah. Sementara saat ini upaya yang dilakukan diperioritaskan kepada pengamanan berupa pemasangan plak kepemilikan tanah, pemasangan patok batas tanah dan pensertifikatan tanah milik Pemerintah Daerah.

\subsection{Kendala-kendala yang Dihadapi dalam Mengimplementasikan Peraturan Pemerintah Nomor 27 Tahun 2014 tentang Pengelolaan Barang Milik Negara/Daerah dalam Upaya Meningkatkan Efektivitas Pengelolaan Barang dan Jasa}

Berdasarkan hasil wawancara dengan Kepala Sub Bidang Perencanaan, Pengadaan dan Penghapusan Barang Milik Daerah (HS), Kepala Sub Bidang penatausahaan dan pelaporan Barang Milik Daerah (DS), Kepala Sub Bidang pemanfaatan dan pengamanan Barang Milik Daerah (WS), Kepala Sub Bidang Umum dan Kepegawaian (DR) dan Pengurus barang Badan Pengelolaan Keuangan Daerah Kabupaten Ciamis (MN), observasi dan dokumentasi terdapat beberapa kendala dalam mengimplementasikan Peraturan pemerintah Nomor 27 Tahun 2014 yaitu sebagai berikut:

1. Kualitas Sumber Daya Manusia (SDM) aparatur barang masih perlu ditingkatkanKualitas SDM berkaitan dengan kemampuan menguasi dan mengoperasikan aplikasi sistem 
informasi manajemen barang milik daerah (SIMDA-BMD) yang akan mengalami perubahan dan pengembangan sesuai perubahan peraturan mengenai tata kelola keuangan dan aset daerah. Hal ini menuntut para pengurus barang maupun operator untuk dapat menguasai dan beradaptasi terhadap sistem tersebut. Hal lain yang menjadi kendala adalah terjadi promosi, mutasi atau pergantian para pengurus barang. Mereka yang telah mahir dalam menatausahakan barang milik daerah, ketika terjadai promosi maupun mutasi seringkali tidak ada kaderisasi, sehingga terjadi kekosongan pengurus barang, hal ini akan berpengaruh terhadap proses penyusunan laporan barang milik daerah di SKPD yang bersangkutan dan akan berpengaruh juga terhadap proses penyusunan laporan barang milik daerah di tingkat kabupaten, oleh karena itu maka aspek SDM pengelola BMD sangat penting artinya dalam proses pengelolaan dan penatausahaan barang milik daerah.

2. Keterbatasan sarana dan prasarana;Sarana yang paling penting dalam hal penatausahaan barang milik daerah adalah komputer atau laptop. Karena setiap tahapan dalam proses penatausahaan barang milik daerah pada akhirnya harus diinputkan ke dalam aplikasi sistem informasi manajemen daerah. Kurangnnya kapasitas atau kemampuan komputer atau laptop dalam memproses data sehingga tidak mampu memproses data yang akhirnya menghambat dalam proses penyusunan data, khususnya data aset tetap.

3. Sistem informasi manajemen aset tetap masih perlu ditingkatkan.Teknologi informasi yang digunakan pada hakekatnya diperlukan untuk membatu mempermudah pekerjaan dalam mencapai tujuan. Begitu juga aplikasi sistem informasi manajemen aset tetap yang digunakan ditujukan untuk mempermudah dalam pengelolaan barang milik daerah sehingga terciptanya administrasi pengelolaan barang milik daerah yang baik. Adakalanya aplikasi sistem yang digunakan belum mengakomodir kebutuhan data yang diakibatkan adanya perubahan peraturan perundangundangan, sehingga aplikasi sistem informasi manajemen aset tetap masih perlu ditingkatkan dan dikembangkan.

\subsection{Upaya-upaya yang Dilakukan dalam Mengimplementasikan Peraturan Pemerintah Nomor 27 Tahun 2014 tentang Pengelolaan Barang Milik Negara/Daerah dalam Upaya Meningkatkan Efektivitas Pengelolaan Barang dan Jasa}

Dalam rangka meningkatkan efktivitas pengelolaan barang milik daerah telah dilakukan upaya-upaya berdasarkan hasil wawancara dengan Kepala Sub Bidang Perencanaan, Pengadaan dan Penghapusan Barang Milik Daerah (HS), Kepala Sub Bidang penatausahaan dan pelaporan Barang Milik Daerah (DS), Kepala Sub Bidang pemanfaatan dan pengamanan Barang Milik Daerah (WS), Kepala Sub Bidang Umum dan Kepegawaian (DR) dan Pengurus barang Badan Pengelolaan Keuangan Daerah Kabupaten Ciamis (MN), observasi dan dokumentasi antara lain :

1. Meningkatkan kompetensi aparatur pengelola barang, bagi para pengurus barang maupun operator dengan diberikannya bimbingan teknis dalam hal pengelolaan barang milik daerah, dilaksanakannya rekonsiliasi dan koordinasi yang melibatkan kasubag umum dan kepegawaian, pengurus barang dan operator secara berkala terkait pengelolaan barang milik daerah. Melalui kegiatan peningkatan kompetensi dengan memberikan bimbingan teknis dalam hal pengelolaan barang milik daerah dari segi biaya 
dirasakan sangat efisien, artinya melalui kegiatan bimbingan teknis tentang pengelolaan barang milik daerah intinya dilakukan transfer ilmu secara menyeluruh terkait pengoperasian sistem tersebut, artinya dengan menggunakan biaya yang relatif sedikit namun hasil yang diperoleh sangat besar, yaitu cakupan jumlah pengurus barang yang memahami dan menguasai aplikasi tersebut secara kuantitas banyak. Jika seluruh pengurus barang menguasi aplikasi tersebut maka hasilnya akan menjadi efektif karena para pengurus barang mampu mengaplikasikannya dilapangan sesuai dengan yang diharapkan. Selanjutnya untuk menjaga konsistensi data aset tetap, maka setiap awal bulan dilaksanakan kegiatan rekonsiliasi data aset antara pengguna barang dengan pembantu pengelola barang, rekonsiliasi ini dilakukan untuk menyamakan realisasi belanja modal tiap-tiap SKPD maupun mutasi barang, baik bertambah maupun berkurang. Bila terjadi perbedaaan akan segera diselesaikan dan ditindaklanjuti pada saat itu juga, sehingga masalahnya tidak menumpuk diakhir tahun dan menyulitkan dalam menelusuri datanya.

2. Pengalokasian anggaran untuk kegiatan pelayanan administrasi perkantoran dan kegiatan peningkatan sarana dan prasarana aparatur dengan pengadaan perangkat komputer yang diperuntukkan bagi 7 (tujuh) kelurahan dan 26 (dua puluh enam) Kecamatan yang digunakan untuk pengelolaan barang milik daerah merupakan satu bukti agar pengelolaan barang milik daerah dapat berjalan dengan baik dan penyediaan ruangan yang dilengkapi dengan server untuk membantu SKPD dalam melakukan rekonsiliasi data aset sehingga bila terjadi perbedaan atau kesalahan data bisa langsung dikoreksi ditempat tanpa harus kembali ketempat kerjanya.
Dengan tersedianya sarana dan prasarana yang memadai maka waktu, tenaga dan biaya yang diperlukan dalam rangka penatausahaan barang milik daerah menjadi lebih efektif dan efisien.

3. Meningkatkan kemampuan aplikasi sistem informasi manajemen pengelolaan barang milik daerah adalah dengan melakukan pengembangan dan pemeliharaan aplikasi sistem informasi manajemen pengelolaan barang milik daerah. Pengembangan ini dilakukan untuk menyediakan data base mengenai kondisi di daerah dari aspek aset daerah yang dapat digunakan untuk penilaian kinerja instansi pemerintah daerah. Menghasilkan informasi yang komprehensif, tepat dan akurat kepada manajemen pemerintah daerah. Informasi ini dapat digunakan sebagai bahan untuk mengambil keputusan serta mempersiapkan aparat daerah untuk mencapai tingkat penguasaan dan pendayagunaan teknologi informasi yang lebih baik.Dalam hal pengembangan aplikasi dimaksud, dilaksanakan dengan melibatkan tim asistensi dari pihak Badan Pengawasan Keuangan dan Pembangunan (BPKP) perwakilan Jawa Barat yang memiliki kewenangan dalam pengembangan sistem aplikasi dimaksud. Pengembangan sistem ini dilakukan sebagai upaya untuk mengatisipasi dan mejawab setiap perubahan kebijakan dalam hal pengelolaan barang milik daerah. Sebagai contoh dengan diberlakukannya Peraturan Pemerintah Republik Indonesia Nomor 71 Tahun 2010 tentang Standar Akuntansi Pemerintah. Berdasarkan peraturan dimaksud pemerintah daerah harus menerapkan laporan keuangan berbasis akrual yang mana dalam penyajian neraca aset tetap harus mencantumkan nilai akumulasi penyusutaan. Maka aplikasi sistem informasi manajemen 
barang daerah juga terus dikembangkan untuk mengakomodir kebutuhan data dimaksud seperti yang diamanatkan dalam perubahan peraturan perundangundangan tersebut.

\section{SIMPULAN}

Berdasarkan pembahasan hasil penelitian, dari mulai wawancara, observasi dan dokumentasi diperoleh kesimpulan sebagai berikut:

1. Implementasi Peraturan Pemerintah Nomor 27 Tahun 2014 tentang Pengelolaan Barang Milik Negara/Daerah dalam upaya meningkatkan efektivitas pengelolaan barang dan jasa yang meliputi perencanaan kebutuhan dan penganggaran, pengadaan, penggunaan, pemanfaatan, pengamanan dan pemeliharaan, penilaian, pemindahtanganan, pemusnahan, penghapusan, penatausahaan, dan pembinaan, pengawasan dan pengendalian secara umum telah dilaksanakan sesuai ketentuan di Kabupaten Ciamis, Namun derajat kesesuaiannya belum mencapai sebagaimana Peraturan Pemerintah Nomor 27 Tahun 2014, hal ini disebabkan terdapat beberapa tahapan yang belum dilaksanakan sesuai ketentuan, diantaranya:

a. Laporan hasil pemeliharaan barang oleh pengguna barang (SKPD) kepada pengelola (Sekretaris Daerah) belum dibuat,

b. Pembantu pengelola barang daerah (BPKD) tidak dapat meneliti dan menyusun daftar hasil pemeliharaan barang dalam satu tahun anggaran untuk dijadikan bahan evaluasi.

c. Pengamanan barang milik daerah khususnya pengamanan yang bersifat fisik seperti pemagaran seluruh tanah milik pemerintah daerah belum dilaksanakan sesuai ketentuan.

2. Kendala-kendala yang dihadapi dalam mengimplementasikan Peraturan Pemerintah Nomor 27 Tahun 2014 tentang Pengelolaan Barang Milik Negara/Daerah dalam upaya meningkatkan efektivitas pengelolaan barang dan jasa adalah sebagai berikut:

a. Kualitas Sumber Daya Manusia (SDM) aparatur barang masih perlu ditingkatkan

b. Keterbatasan sarana dan prasarana;

c. Sistem informasi manajemen aset tetap masih perlu ditingkatkan.

3. Upaya-upaya yang dilakukan dalammengimplementasikan Peraturan Pemerintah Nomor 27 Tahun 2014 tentang Pengelolaan Barang Milik Negara/Daerah dalam upaya meningkatkan efektivitas pengelolaan barang dan jasa adalah sebagai berikut:

a. Meningkatkan Kompetensi SDM melalui bimbingan teknis pengelolaan barang milik daerah secara konsisten dan berkesinambungan.

b. Pemenuhan sarana dan prasarana kerja bagi para pengelola barang daerah yaitu melalui pemberian komputer beserta printer bagi 7 (tujuh) Kelurahan dan 26 (dua puluh enam) Kecamatan se-Kabupaten Ciamis.

c. Pengembangan Aplikasi Sistem Manajemen Informasi Barang Daerah melalui peningkatan kapasitas (versi) sehingga mampu memenuhi data yang dibutuhkan, contohnya akumulasi penyusutan. 


\section{DAFTAR PUSTAKA}

Atmosoeprapto, Kisdarto, (2012). Мепијu SDM Berdaya. Jakarta : Elex Media.

Darise, Nurlan, (2009). Pengelolaan Keuangan Daerah. Jakarta : Indeks.

Dunn, William N., (2013). Pengantar Analisis Kebijakan Publik. Yogyakarta: UGM.

Gibson, James L, Ivancevich, John M, Donnely, James H, Jr, Adiarni, Nunuk (Penterjemah)., (2006). Organisasi, Perilaku, Struktur, Proses, Jakarta : Bina Aksara.

Hasibuan, Malayu S.P., (2005). Manajemen Dasar, Pengertian, dan Masalah. Jakarta: Bumi Aksara.

Mardiasmo, (2012). Prinsip-Prinsip Manajemen Dalam Pembiayaan Desentralisasi. Yogyakarta: FE-UGM.

Moleong, J., (2009). Lexy, Metode Kualitatif Edisi Revisi.

Osborn David and Plastrik, (2007). Banishing Bureacracy (The Five Strategy for Reinventing Government). New York : Addison-Wesley Publishing, Inc.

Widodo, Joko, (2009). Analisis Kebijakan Publik. Jakarta: Bumi Aksara.

Winarno, Budi, (2012). Teori dan Proses Kebijakan Publik. Yogjakarta: Madia.

Syarifudin, D., \& Herlina, E. (2009). Analisis Kemandirian Kinerja Kewilayahan Garut Selatan Menjadi Daerah Otonomi Baru (DOB): Studi Pemekaran Daerah Garut Selatan di Kabupaten Garut. Jurnal Manajemen dan Pemasaran 13 (2), 49-66.

, Peraturan Pemerintah Nomor 27 Tahun 2014 Tentang Pengelolaan Barang Milik Negara/Daerah.

, Permendagri Nomor 17 tahun 2007 tentang pedoman teknis pengelolaan barang milik daerah 